\title{
NYAI DASIMA
}

\author{
Oleh : Novianti
}

Pembimbing Tugas Akhir: Dindin Heryadi, M.Sn dan Ni Kadek Rai Dewi Astini, M.Sn)

Jurusan Tari, Fakultas Seni Pertunjukan Institut Seni Indonesia Yogyakarta

Alamat Email: noviantifachmi@yahoo.com

\section{RINGKASAN}

Karya tari "Nyai Dasima" terinspirasi dari ketertarikan penata untuk membuat karya tari bernuansa Betawi dengan bekal pengetahuan tentang tari Betawi yang pernah dipelajari penata. Selain itu juga karena ketertarikan penata terhadap salah satu cerita rakyat yang sudah melegenda di Jakarta tentang tokoh Nyai Dasima yang ditulis oleh S.M Ardan dalam bukunya berjudul "Nyai Dasima”.

Ketertarikan tersebut menjadi dorongan bagi penata untuk mewujudkan cerita Nyai Dasima yang ditulis oleh S.M Ardan untuk diwujudkan dalam bentuk karya seni pertunjukan khususnya karya tari. Karya tari ini memvisualisasikan sosok Nyai Dasima dan cerita cinta segitiga yang membawa petaka bagi dirinya.

Karya tari ini diciptakan dalam koreografi kelompok dengan 13 penari yang terdiri dari empat penari wanita dan sembilan penari laki-laki. Karya tari ini dipentaskan di dalam ruang pertunjukan proscenium stage dengan setting yang mendukung karya ini. Jenis musik yang digunakan untuk mendukung karya tari ini adalah live music. Lewat karya ini penata ingin menyampaikan bahwa tidak selalu sebutan "Nyai" memiliki konotasi negatif khususnya dalam cerita Nyai Dasima.

Kata kunci: Nyai Dasima, Cerita rakyat, Betawi

\section{ABSTRACT}

The choreography of "Nyai Dasima" is inspired by the choreographer's interest in the creation of Betawi Dance with all of her knowledge learnt about it. Moreover the choreographer is intrigued by the legend about a person named Nyai Dasima written by S.M Ardan in a book called "Nyai Dasima". 
This interest motivated the choreographer to create performing arts especially dance choreography about Nyai Dasima. This choreography visualized Nyai Dasima and her tragic love story.

This dance choreography is created for a team of 13 dancers. There are four female dancers and nine male dancers. This dance work is performed in the proscenium stage show hall with a setting that supports this work. The music used is a live music. With this dance work the choreographer wants to tell people that the character of "Nyai", especially in Nyai Dasima story, does not always have a negative connotation.

\section{Keywords: Nyai Dasima, Folklore, Betawi}

\section{PENDAHULUAN}

Indonesia adalah negara yang kaya dengan keberagaman suku di dalamnya, dari banyaknya suku tersebut maka kebudayaan yang dihasilkan juga beragam begitu pula dengan kesenian dari masing-masing suku atau daerah. Di Jakarta sendiri terdapat kesenian tari, kesenian lenong, kesenian musik gambang kromong dan juga cerita rakyat yang sudah melegenda. Jakarta sama dengan daerah lain juga memiliki cerita rakyat yang sudah melegenda. Cerita rakyat adalah cerita yang berasal dari masyarakat dan berkembang dalam masyarakat pada masa lampau yang menjadi ciri khas setiap bangsa yang memiliki kultur budaya yang beraneka ragam mencakup kekayaan budaya dan sejarah yang dimiliki masing-masing bangsa ${ }^{1}$.

\footnotetext{
${ }^{1}$ https://mynameis8.wordpress.com, diunggah pada 1 Agustus 2013 diunduh tgl 1 September 2016.
}

Cerita rakyat yang masih sering terdengar di Jakarta hingga saat ini adalah tentang tokoh wanita yang bernama Nyai Dasima. Nyai Dasima adalah wanita yang berasal dari dusun Kahuripan, desa Cise'eng, Bogor Jawa Barat, yang dijadikan gundik atau bini piara oleh seorang laki-laki yang berkebangsaan Inggris bernama Edward William yang biasa dipanggil Tuan W, lalu dibawa ke Batavia. Nyai Dasima adalah seorang wanita yang diceritakan memiliki paras yang cantik, berkulit putih bersih dan memiliki rambut panjang ${ }^{2}$. Semula Nyai Dasima dan Tuan W menetap di Curug Tangerang, kemudian pindah ke Pejambon Batavia.

Kata Nyai hadir dan tercatat dalam sejarah selain itu juga ia menjadi tema serta motif sastra yang terus menerus mendapat

\footnotetext{
${ }^{2}$ S.M Ardan, Nyai Dasima, 2007, p.75
} 
perhatian ${ }^{3}$. Suatu cerita rakyat yang melegenda dalam satu daerah belum tentu diketahui oleh masyarakat di daerah lainnya. Penata sendiri merasa miris manakala orang yang berasal dari daerah lain menyebut bahwa Nyai Dasima adalah sosok wanita penggoda, padahal belum tentu kebenarannya, bahkan sebagian orang sendiri tidak tahu persis informasi tersebut didapatkannya dari sumber mana. Oleh sebab itu lewat karya tari "Nyai Dasima" ini ingin memberitahukan kepada masyarakat luas bahwa kata "Nyai" tidak selamanya memiliki konotasi negatif. Untuk memperkuat argumen tersebut penata mencari sumber tentang Nyai Dasima maupun tentang kehidupan sosial di Jakarta yang pada saat itu masih bernama Batavia. Buku berjudul "Nyai Dasima" yang ditulis ulang oleh S.M Ardan, buku berjudul "Sastra, Perempuan, Seks" yang ditulis oleh Katrin Bandel dan buku berjudul "Batavia 1740 Menyisir Jejak Betawi” yang ditulis oleh Windoro Adi banyak mengulas hal tersebut.

Karya tari berjudul "Nyai Dasima" ini penata menunjukan kisah hidup Nyai Dasima dan ingin memvisualisasikan sosok Nyai yang terdapat dalam buku "Nyai Dasima" yang menceritakan kisah cinta segitiga yang berujung petaka, selain itu juga sedikit menceritakan tentang sosok Nyai yang ingin kembali ke tengah bangsanya ${ }^{4}$. Kisah yang ingin divisualkan akan ditransformasikan

${ }^{3}$ S.M Ardan, Nyai Dasima, 2007, p.xix

${ }^{4}$ S.M Ardan, Nyai Dasima, 2007, p.xix dalam bentuk gerak tari, gerak tari yang akan ditampilkan yaitu gerak yang diciptakan penata yang sesuai dengan penggambaran isi cerita dan juga berdasarkan gerak-gerak khas tari Betawi dan silat Betawi.

\section{PEMBAHASAN}

\section{A. Proses Penciptaan}

\section{Rangsang Awal}

Rangsang tari adalah sesuatu yang menjadi dasar dalam menciptakan karya tari. Rangsang Tari dapat diartikan sebagai sesuatu yang membangkitkan fikir, semangat atau mendorong kegiatan. Rangsang bagi komposisi tari dapat berupa auditif, visual, gagasan, rabaan dan kinestetik ${ }^{5}$. Karya tari "Nyai Dasima" ini menggunakan rangsang gagasan (idesional). Gerak dirangsang dan dibentuk dengan intensi untuk menyampaikan gagasan atau menggelarkan cerita ${ }^{7}$. Rangsang tari disini sebagai langkah awal bagi penata dalam menentukan apa yang akan dibuat.

Rangsang gagasan atau Idesional merupakan rangsang yang dialami penata sebelum memulai proses penciptaan karya ini, karena penata merasa terinspirasi setelah membaca buku berjudul "Nyai Dasima" yang ditulis oleh S.M Ardan. Ketertarikan tersebutlah yang akhirnya menjadi sumber

\footnotetext{
${ }^{5}$ Jacqueline Smith, Komposisi tari: Sebuah Petunjuk Praktis Bagi Guru, Terjemahan Ben Suharto, 1985, p.20
} 
bagi penata untuk mewujudkan karya tari "Nyai Dasima".

\section{Tema Tari}

Tema dalam sebuah karya yaitu ide atau gagasan berisi muatan yang ingin disampaikan dan ditampilkan yang pada akhirnya akan menjadi batasan-batasan penata dalam menciptakan karya. Tema yang diangkat dalam karya "Nyai Dasima" yaitu tentang cerita cinta Dasima yang berujung tragis, kepiluan serta kebimbangan Dasima dalam meraih keinginannya untuk kembali berada di tengah-tengah masyarakat pribumi berikut dengan penggambaran karakter Dasima.

\section{Judul Tari}

Judul adalah nama yang dipakai untuk buku atau bab dalam buku yang dapat menyiratkan secara pendek isi atau maksud buku atau bab itu ${ }^{6}$. Selain itu judul juga dapat dijadikan identitas karya yang dapat menjadi sumber informasi singkat tentang apa yang akan disampaikan oleh penata dalam karya tarinya. Judul dari karya tari yang diciptakan adalah "Nyai Dasima". Sebuah judul yang hendaknya sesuai dengan apa yang ingin disampaikan yaitu tentang sosok wanita dalam cerita dari sebuah buku yang mengispirasi penata. "Nyai Dasima" dipilih karena nama "Nyai Dasima" cukup familiar dikalangan masyarakat meskipun masyarakat itu sendiri

${ }^{6}$ http://kbbi.web.id/judul, diunggah tgl 1 September 2016 memiliki pandangan masing-masing tentang Nyai Dasima.

\section{Tipe Tari}

Karya tari ini menjadi karya tari bertipe dramatari yang mengandung arti bahwa karya tari yang disajikan memiliki cerita untuk diungkapkan ${ }^{7}$. Cerita yang ingin diungkapkan dalam karya tari ini adalah cerita tentang seorang wanita bernama Nyai Dasima. Diceritakan kisah cinta Dasima yang berujung tragis, kepiluan serta kebimbangan Dasima dalam meraih keinginannya untuk kembali berada di tengah-tengah masyarakat pribumi berikut dengan penggambaran karakter Dasima.

\section{Mode Penyajian}

Cara ungkap maksud dan tujuan karya secara langsung maupun tidak langsung termasuk dalam mode penyajian. Dijelaskan dalam buku Jacqueline Smith Komposisi Tari: Sebuah Petunjuk Praktis Bagi Guru terjemahan Ben Suharto bahwa mode penyajian tari ada dua macam yaitu representasional dan simbolik ${ }^{8}$. Di dalam karya tari "Nyai Dasima" ini mode penyajian yang dipilih adalah keduanya yaitu representasional dan simbolik.

\footnotetext{
${ }^{7}$ Jacqueline Smith, Komposisi tari: Sebuah Petunjuk Praktis bagi Guru, Terjemahan Ben Suharto, 1985, p.27

${ }^{8}$ Jacqueline Smith, Komposisi tari: Sebuah Petunjuk Praktis bagi Guru, Terjemahan Ben Suharto, 1985, p.29
} 


\section{Gerak Tari}

Gerak adalah dasar ekspresi, oleh sebab itu gerak kita pahami sebagai ekspresi dari semua pengalaman emosional. Ekspresi adalah gerakan-gerakan yang sudah dipolakan menjadi bentuk yang dapat dikomunikasikan secara langsung lewat perasaan ${ }^{9}$. Gerak yang digunakan dalam karya tari ini yaitu berdasarkan gerak-gerak khas Betawi seperti selancar, miwir ampok, kewer dan gibang untuk penari wanita sedangkan untuk penari laki-laki mengembangkan dasar-dasar dari silat Betawi dan gerak jalan. Gerak-gerak tersebut dikembangkan dan divariasikan sesuai dengan kebutuhan karya. Selain itu juga menggunakan gerak yang dapat mewakili perasaan yang ingin disampaikan.

\section{Adegan Tari}

Adegan tari dalam karya ini terbagi menjadi lima bagian. Dimulai dari introduksi oleh satu orang penari perempuan dan laki-laki yang menjadi tokoh Dasima dan Samiun pada saat terbunuhnya Dasima. Adegan 1 yaitu menggambarkan tentang karakter Dasima dengan menampilkan empat orang penari wanita, tidak hanya itu dalam adegan satu ini juga ditampilkan kemeriahan masyarakat Betawi pada saat tari berpasangan. Pada adegan tiga disitulah dimunculkan konflik antara Dasima, Samiun dan Tuan W, dan pada akhirnya Dasima memilih berada dipihak

\footnotetext{
${ }^{9}$ Y. Sumandiyo Hadi, Koreografi (Bentuk-Teknik-Isi), 2011, p.10
}

Samiun, hal itu yang menyebabkan amarah Tuan W memuncak sehingga terjadi perkelahian antara anak buah Tuan $\mathrm{W}$ dan Jawara Betawi. Selanjutnya pada bagian akhir ditampilkan kembali saat dasima sudah terbunuh dan yang tersisa hanya kepedihan Samiun dan Tuan W.

\section{Penari}

Karya tari ini ditarikan oleh 13 orang. Sosok dan karakter Nyai Dasima ditarikan oleh empat orang penari wanita yang salah satu sebagai tokoh dan didukung oleh penari wanita lainnya sebagai pendukung suasana atau penggambaran suasana hati Dasima. Sosok Tuan W ditarikan oleh satu orang penari laki-laki dan empat orang penari laki-laki sebagai tentara Inggris. Lalu sosok Samiun juga ditarikan oleh satu orang penari laki-laki dan empat orang penari laki-laki yang menjadi penggambaran tokoh dan bisa saja sebagai teman-teman Samiun di kampung Pejambon. Pemilihan penari juga menjadi pertimbangan penata yaitu penari yang memiliki kemampuan yang mampu untuk mendukung karya ini dan penari yang memiliki disiplin waktu yang baik. Pemilihan jumlah penari dianggap penata sesuai dengan kebutuhan karya ini.

\section{Rias dan Busana}

Rias yang digunakan dalam karya ini merupakan tipe rias karakter dan korektif. Penata mewujudkan sosok Nyai Dasima, Tuan 
W dan Samiun. Sosok Dasima Wanita yang sehari-harinya mengenakan kebaya dan suatu ketika menggunakan pakaian yang bagus dan nyentrik, Tuan W yang selalu berseragam tentara lengkap dengan senapannya dan Samiun yang selalu menggunakan Baju Pangsi yaitu semacam baju silat yang biasa dipakai jawara-jawara Betawi dengan ikat pinggang besar selalu melingkar di bagian perutnya.

\section{Musik Tari}

Musik merupakan salah satu elemen penting pendukung karya tari. Musik bisa juga dijadikan patokan gerak selain sebagai ilustrasi dan pendukung suasana. Dalam karya tari ini penata menyajikan format music live dengan instrumen-instrumen bernuansa Betawi dan digarap sesuai dengan kebutuhan karya dan keselarasan antara tari dan musik.

\section{Tata Rupa Pentas}

Karya tari ini menampilkan adegan dibunuhnya Dasima dengan menghadirkan bantuan setting artistik dengan mengangkat backdrop sisi sebelah kiri up stage, sebagai simbol masa lalu yang diwujudkan dalam ruang yang berbeda dari adegan lainnya.

\section{Pencahayaan}

Tata Cahaya sangat penting peranannya dalam seni pertunjukan, yang mana harus mampu menciptakan suatu nuansa yang luar biasa $^{10}$. Pencahayaan menjadi unsur penting karena selain menghadirkan suasana

${ }^{10}$ Hendro Martono, Menganal Tata Cahaya Seni pertunjukan,2010, p.11 pencahayaan juga membentuk ruang, dan waktu yang dihadirkan. Pencahayaan yang digunakan adalah warna-warna yang mampu menghadirkan suasana sekaligus memperjelas tangga dramatik dari alur cerita dalam karya tari ini.

\section{B. Realisasi Karya \\ 1. Realisasi Musik Tari}

Pemilihan dan penetapan musik yang dipilih penata yaitu musik dalam format live. Live music dipilih karena menurut penata sesuai dengan kebutuhan karya yang akan dibuat. Karya tari "Nyai Dasima" memiliki latar belakang tempat di Jakarta tentunya memiliki khas musik Betawi, hal tersebut membuat penata memilih dan menetapkan penata musik yang dipercaya oleh penata mampu merealisasikan yang diinginkan penata yaitu Adimas Muhammad Fajariansyah. Setelah itu penata tari dan penata musik menentukan pemusik yang mampu memainkan alat musik yang sudah dipilih, yaitu Kendang, Bonang, Gambang, Kecrek, Erhu, Bass, Terompet, Keyboard, Suling, Gong, Kempul, Chims dan Cymbal.

\section{Realisasi Tata Rias dan Busana}

Pemilihan rias korektif dan karakter dipilih untuk mempertegas raut muka agar nampak jelas di atas panggung. Pemakaian lipstik berwarna merah yang diaplikasikan pada penari wanita yang menjadi kelompok 
Dasima diharapkan dapat menjadi ciri kewanitaan. Penggunaan brewok dengan bulubulu hitam yang ditempel untuk membuat kumis dan brewok yang di aplikasikan pada penari laki-laki yang menjadi Jawara Betawi juga diharapkan dapat menimbulkan kesan gagah dan berani. Sedangkan untuk penari yang menjadi tentara Inggris menggunakan cat rambut pirang atau kekuningan dan rias korektif yang diharapkan dapat menjadi ciri bahwa tentara Inggris bukan dari Indonesia yang umumnya memiliki warna rambut hitam. Selain itu untuk dua orang pemantun dan pemusik juga diberikan rias natural.

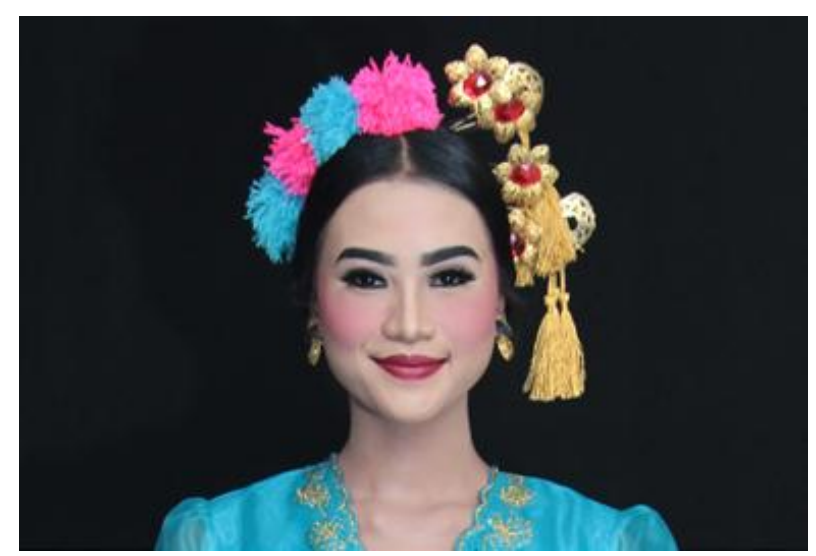

Gambar 1: Desain rias untuk penari wanita dan Dasima. (foto: Ari Kusuma, 2017, di Yogyakarta)

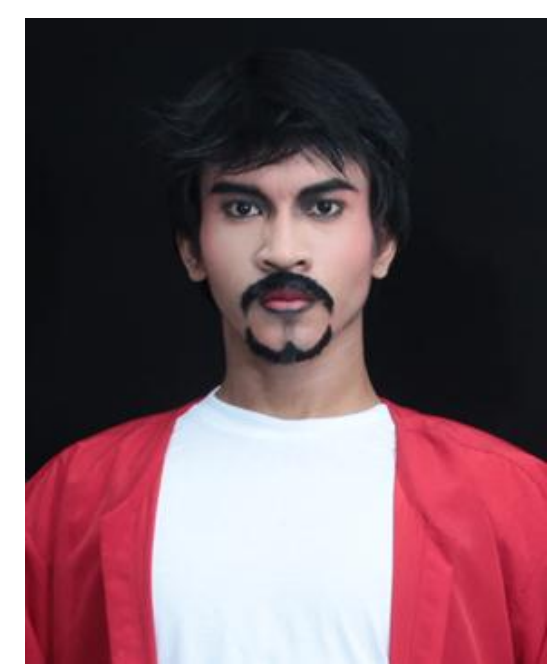

Gambar 2 : Desain rias untuk penari laki-laki Samiun dan Jawara Betawi. (foto: Ari Kusuma, 2017, di Yogyakarta)

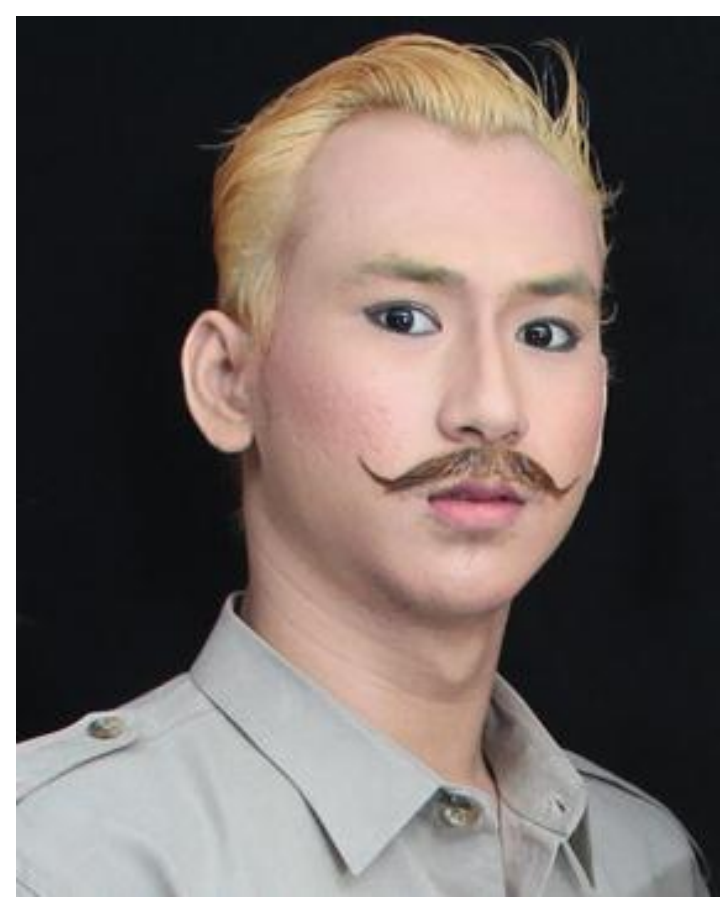

Gambar 3: Desain rias untuk penari laki-laki Tuan W dan Tentara Inggris. (foto: Ari Kusuma, 2017, di Yogyakarta)

Busana yang diwujudkan disini busana sosok Dasima Wanita yang sehari-harinya mengenakan kebaya dan suatu ketika menggunakan pakaian yang agak nyentrik dengan kebaya bertangan terompet sebagai identitas Betawi. Tuan W yang selalu berseragam tentara lengkap dengan senapan dan sepatunya. Samiun yang selalu menggunakan Baju Pangsi yaitu semacam baju silat yang biasa dipakai jawara-jawara betawi dengan ikat pinggang besar selalu melingkar di bagian perutntya.

Pemantun diberikan busana sehari-hari masyarakt Betawi zaman dahulu yaitu dengan kaos putih polos, bercelana batik, 
menggunakan peci dan sarung yang diikat dipinggang, sedangkan untuk pemusik juga serupa hanya saja sarung dikalungkan dileher dan untuk pemusik wanita busana yang digunakan adalah kebaya dengan kain batik Betawi dan kerudung.

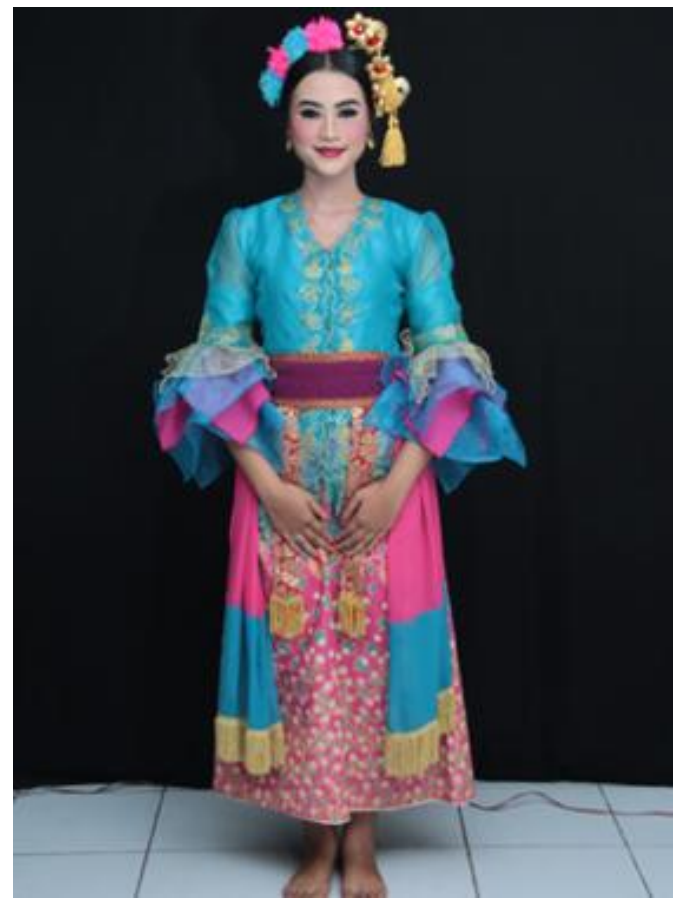

Gambar 4: Desain busana untuk penari wanita dan Dasima. (tampak depan) (foto: Ari Kusuma, 2017, di Yogyakarta)

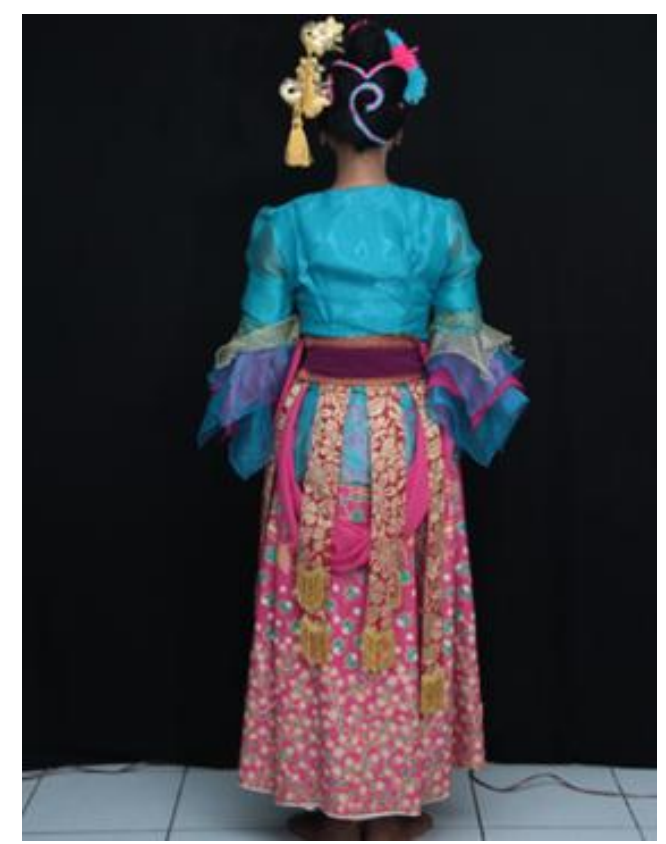

Gambar 5: Desain busana untuk penari wanita dan Dasima. (tampak belakang) (foto: Ari Kusuma, 2017, di Yogyakarta)

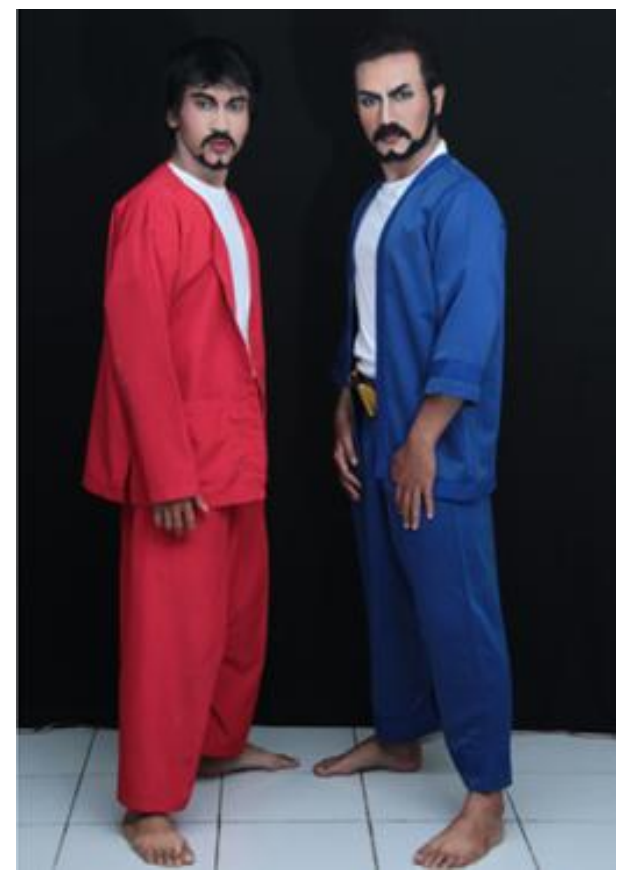

Gambar 6: Desain busana penari laki-laki Samiun dan Jawara Betawi. (foto: Ari Kusuma, 2017, di Yogyakarta)

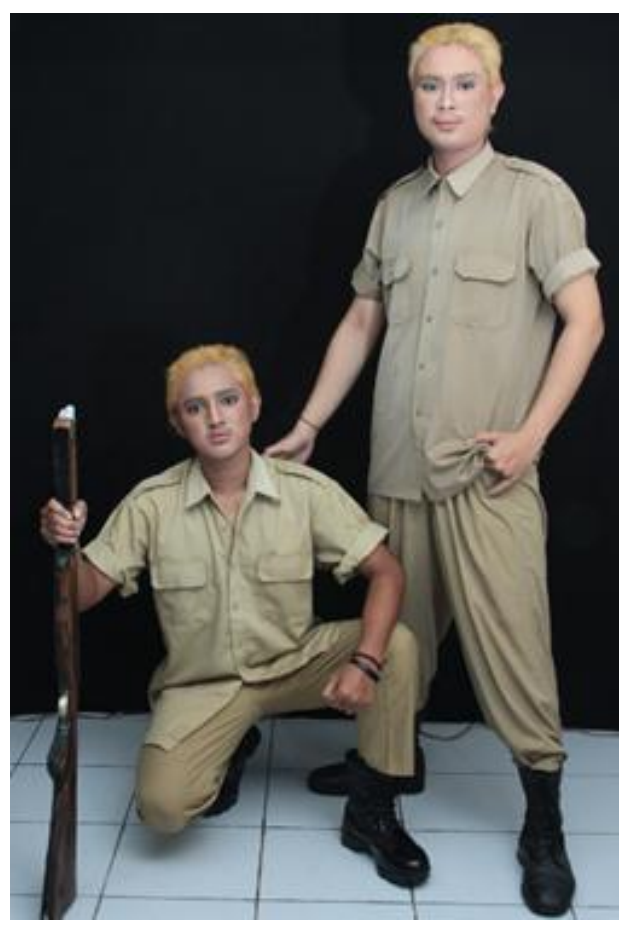

Gambar 7: Desain busana penari laki-laki Tuan W dan Tentara Inggris. (foto: Ari Kusuma, 2017, di Yogyakarta) 


\section{Evaluasi}

\section{Introduksi}

Bagian introduksi dimulai dengan menyuguhkan musik bernuansa Betawi yang meriah dilanjutkan dengan menceritakan dalam bentuk visual kejadian dibunuhnya Dasima pada saat Dasima sedang berkasihkasihan dengan Samiun. Samiun sedih dan marah ingin mengejar pelaku pembunuhan Dasima, tetapi Dasima menahannya untuk tetap bersamanya.

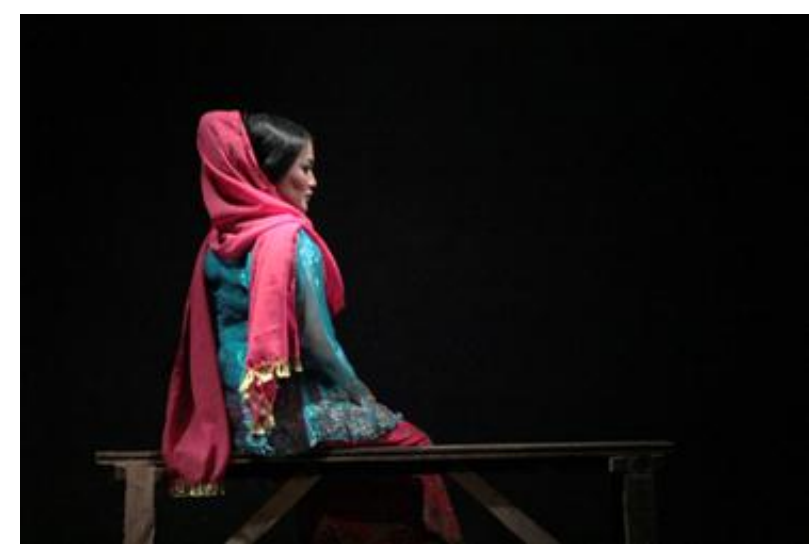

Gambar 8: Adegan introduksi saat Dasima menunggu kedatangan Samiun. (foto: Ari Kusuma, 2017, di Yogyakarta)

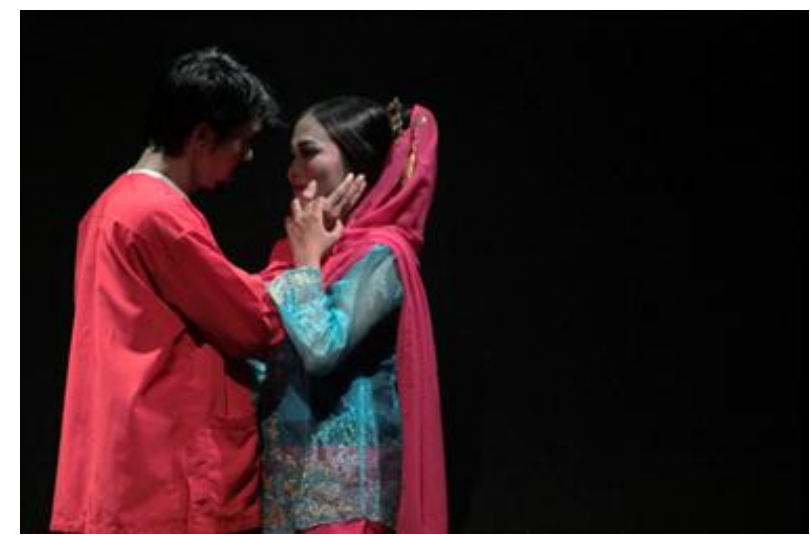

Gambar 9: Adegan introduksi saat Dasima dan Samiun memadu kasih. (foto: Ari Kusuma, 2017, di Yogyakarta)

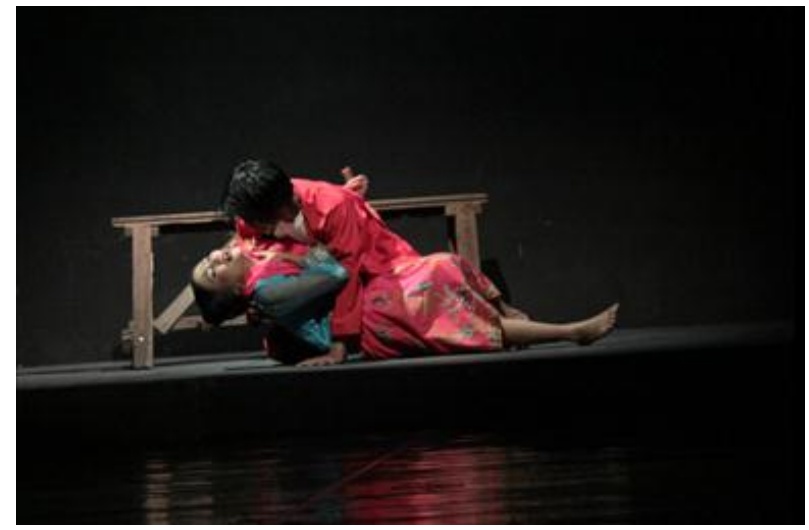

Gambar 10: Ekspresi kesakitan Dasima pada saat terbunuh. (foto: Ari Kusuma, 2017, di Yogyakarta)

\section{Adegan 1}

Pada adegan 1 ini penata memvisualisasikan karakter Nyai Dasima yaitu sebagai wanita yang molek, anggun dan lemah lembut seperti kecantikannya yang sontak saja dapat menarik perhatian laki-laki manapun yang melihatnya.

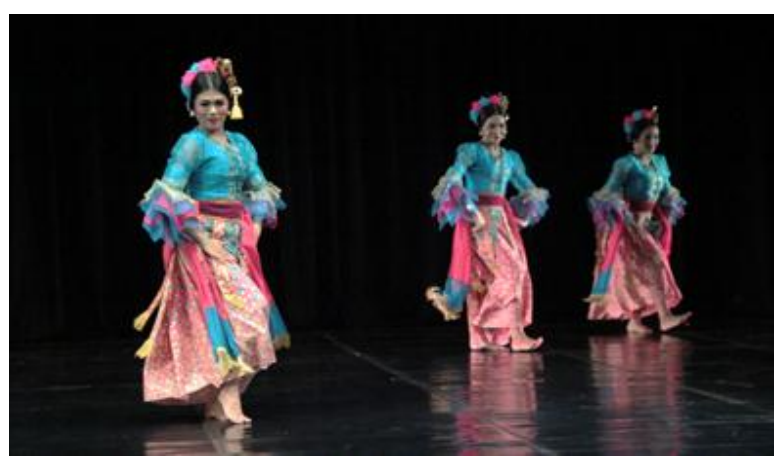

Gambar 11: Keempat penari wanita yang mewakili sebagai kelompok Dasima pada Adegan 1. (foto: Ari Kusuma, 2017, di Yogyakarta)

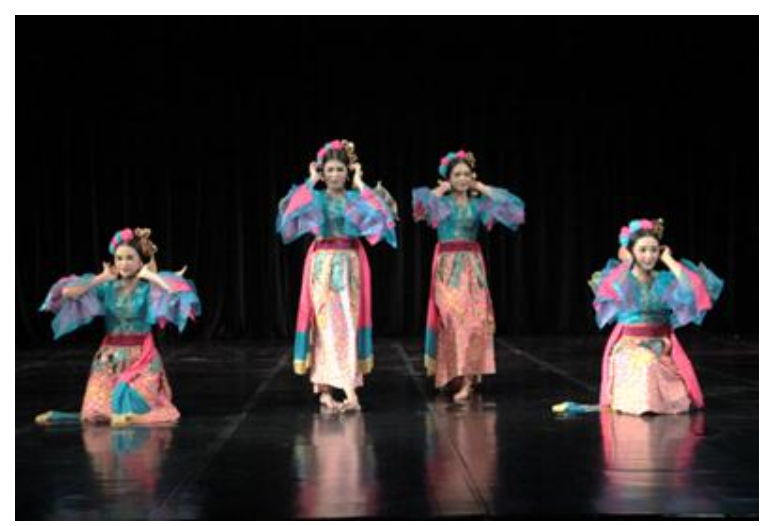


Gambar 12: Keempat penari wanita yang mewakili sebagai kelompok Dasima pada Adegan 1. (foto: Ari Kusuma, 2017, di Yogyakarta)

Pada saat yang bersamaan di sisi yang berbeda Dasima tidak sadar bahwa dirinya sedang diperhatikan oleh pemuda kampung dari kejauhan.

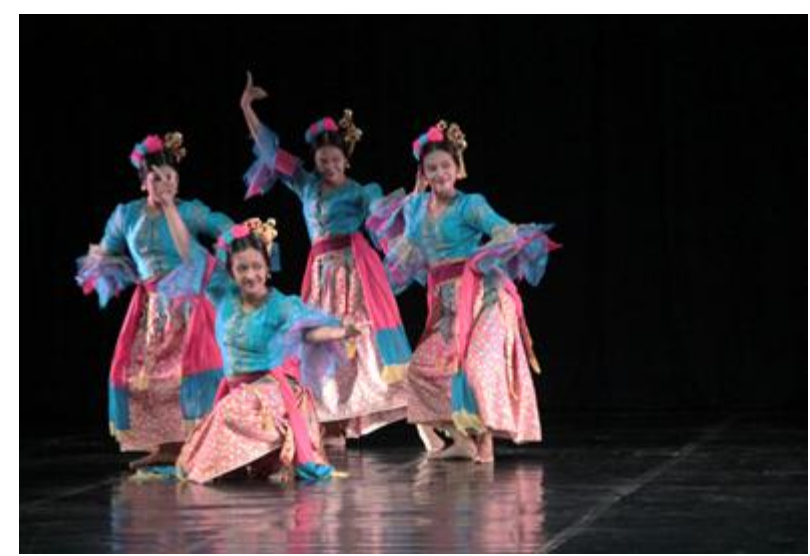

Gambar 13: Kelompok Dasima yang sedang memperhatikan kedatangan kelompok Samiun. (foto: Ari Kusuma, 2017, di Yogyakarta)

\section{Adegan 2}

Masih dengan menampilkan empat penari wanita sebagai penggambaran sosok Dasima. Pada saat kelompok Dasima sedang menari setelah ditinggal Jawara Betawi lalu masuklah penari yang berperan sebagai Tuan W yang mengamati wanita-wanita sedang menari dan mendekati salah satu penari yang menjadi tokoh Nyai dasima. Terjadilah love dance antara Dasima dan Tuan W.

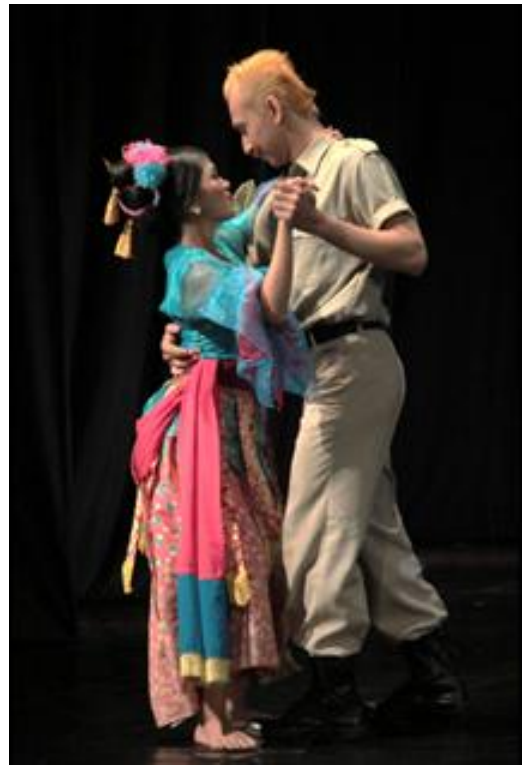

Gambar 14: Dasima dan Tuan W pada saat love dance di adegan 2. (foto: Ari Kusuma, 2017, di Yogyakarta)

\section{Adegan 3}

Pada adegan ini disuguhkan salah satu kebudayaan Betawi yaitu berbalas pantun yang juga sebagai penggambaran masyarakat Betawi. Pantun selain sebagai salah satu penunjukan kebudayaan Betawi juga sebagai transisi dalam adegan ini, karena dalam adegan ini menampilkan juga kemampuan silat dari Jawara Betawi ditampilkan dalam konsep latihan silat.

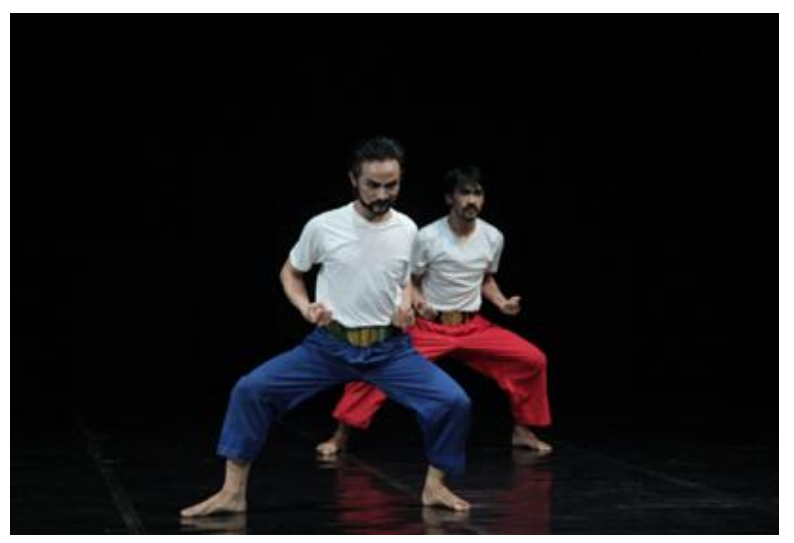

Gambar 15: Salah satu Jawara Betawi dan Samiun pada saat berlatih silat. (foto: Ari Kusuma, 2017, di Yogyakarta) 


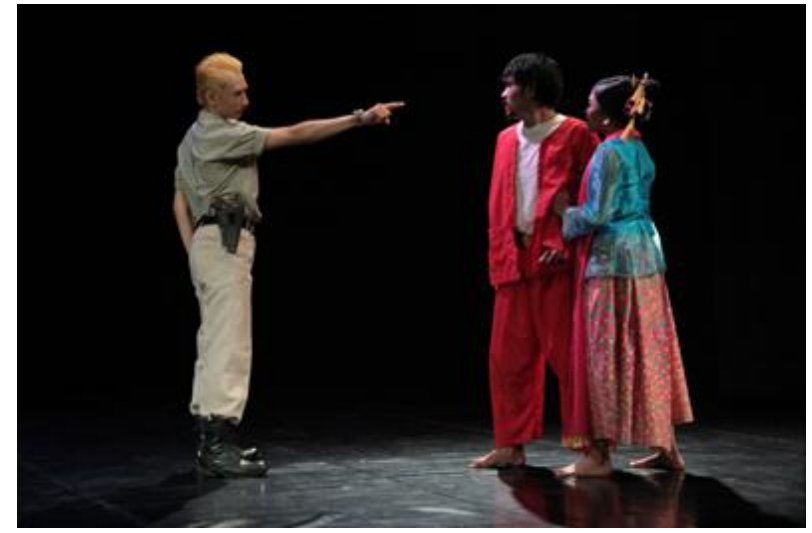

Gambar 16: Ekspresi kemarahan Tuan W pada saat Dasima Memilih bersama Samiun. (foto: Ari Kusuma, 2017, di Yogyakarta)

Ketika Tuan W sedang bersama Dasima di sisi lain Samiun juga hadir. Maka disitulah konflik terjadi dan Dasima memilih bersama Samiun. Tuan W menyimpan kekecewaan dan amarah, maka diperintahkannya tentara Inggris untuk menyerang kelompok Jawara Betawi, terjadilah perkelahian yang akhirnya dimenangkan oleh kelompok Jawara Betawi.

\section{Adegan 4/Ending}

Pada adegan 4 ini penata mencoba mengingatkan kembali pada penyajian awal yang dibuka oleh sosok Dasima dan Samiun, maka dalam adegan ini penata menghadirkan kembali sampai akhirnya Samiun sendiri dan meratapi kematian Dasima. Samiun tidak dapat berbuat apa-apa untuk menahan rasa sedih dan amarahnya menyaksikan kematian Dasima, ia hanya mampu meneriakan nama perempuan yang dicintainya "Dasimaaa..."

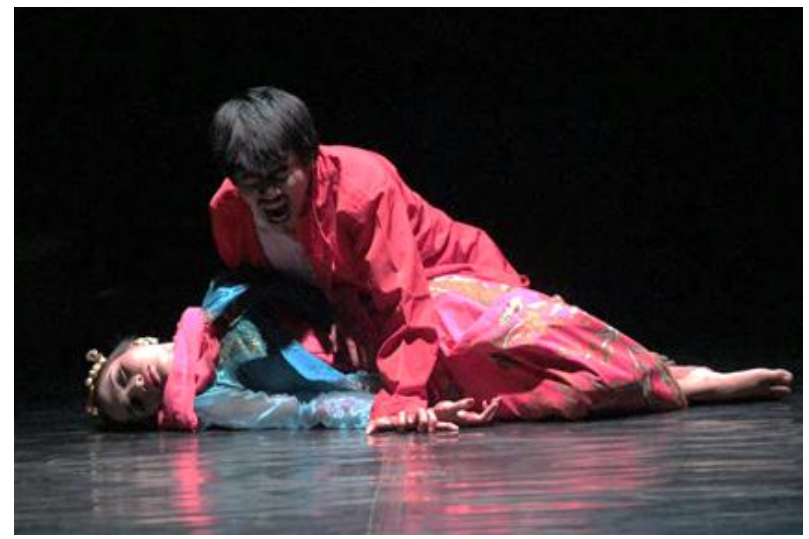

Gambar 18: Ekspresi Samiun pada saat meneriakan nama Dasima. (foto: Ari Kusuma, 2017, di Yogyakarta)

\section{PENUTUP}

Proses penciptaan suatu karya tentunya memiliki keberhasilan dan kendala dalam setiap perjalanannya., begitu pula dalam proses penciptaan karya tari "Nyai Dasima". Karya tari "Nyai Dasima" diciptakan karena keinginan penata untuk memperkenalkan dan mendalami kembali pengetahuan penata tentang tari Betawi dengan membawakan cerita kisah cinta segitiga dari seorang perempuan bernama Nyai Dasima.

$$
\text { Karya tari berjudul "Nyai Dasima", }
$$
menceritakan tentang cerita cinta Dasima yang berujung tragis, kepiluan serta kebimbangannya dalam meraih keinginannya untuk kembali berada di tengah-tengah masyarakat kampung. Perasaan rindunya dan juga karena merasa sudah tidak sanggup lagi berada di dalam rumah gedong yang sama sekali tidak mengindahkan keberadaannya, hal itu lah yang mendasari Dasima akhirnya menjalin hubungan dengan Samiun seorang 
pemuda Betawi, selain itu diceritakan juga sosok bernama Edward William yang biasa dipanggil Tuan $\mathrm{W}$ yaitu laki-laki berkebangsaan Inggris yang menjadikan Dasima bini piara dan Samiun adalah lelaki berdarah Betawi yang akhirnya memikat hati Dasima dan membuatnya semakin ingin terlepas dari Tuan W. Sayangnya kisah cinta segitiga tersebut tidak berakhir indah, tapi justru membawa petaka bagi Nyai Dasima.

Dari cerita tersebut penata juga ingin menyampaikan bahwa tidak selamanya kata "Nyai" dipandang sebagai sesuatu yang negatif. Terbukti pada cerita Nyai Dasima, begitu pahit hidup yang harus dijalani sampai keadaan memaksanya bersedia menjadi bini piara dari seorang lelaki berkebangsaan Inggris, setelah itu hanya kebahagiaan sesaat yang Dasima rasakan, kelanjutannya Ia malah merasa tersiksa hidup dibatasi dengan tidak boleh bergaul dengan orang-orang di sekitarnya.

Lewat karya tari "Nyai Dasima" penata berharap penonton dapat menikmati hasil dari proses penciptaan yang dilakukan selama tiga bulan dengan penuh cerita dan suka cita. Akhirnya penata memohon maaf jika dalam karya tari ini masih banyak keterbatasan yang belum mampu dilewati, semoga dalam karya selanjutnya penata dapat menciptakan karya tari yang lebih baik. Terimakasih.

\section{DAFTAR SUMBER ACUAN}

\section{A. Sumber Tertulis}

Adi, Windoro. 2010. Batavia 1740 : Menyisir Jejak Betawi. Jakarta: Garmedia Pustaka Tama.

Adi Darmarastri, Hayu. 2003. Nyai Batavia. Jakarta: Grafindo

Ardan, S. M. 2007. Nyai Dasima. Jakarta: Masup Jakarta.

Arunita, Rachmania. Koma. 2013. Yogyakarta: Bentang Pustaka

Ataladjar, Thomas B. 2003. Toko Merah. Jakarta: Dinas Kebudayaan Dki Jakarta.

Bandel, Katrin. 2006. Satra, Perempuan, Seks. Yogyakarta: Jalasutra.

Budiaman. 1979. Folklor Betawi. Jakarta: Pustaka Jaya.

Francis, G. 2007. Tjerita Njai Dasima. Jakarta: Masup Jakarta.

Grijns, C.D. 1991. Kajian Bahasa Melayu-Betawi. Jakarta: Pustaka Utama Grafiti.

Hadi, Y. Sumandiyo. 1996. Aspek aspek dasar KOREOGRAFI KELOMPOK. Yogyakarta : Manthili Yogyakarta.

Tehnik-Isi). Yogyakarta: Cipta Media.

Haris, Tawalinuddin. 2007. Kota dan Masyarakat Jakarta. Jakarta: Wedatama Widya Sastra.

Martono, Hendro. 2010. Mengenal Tata Cahaya Seni Pertunjukan. Yogyakarta: Cipta Media. 
2012. Ruang

Pertunjukan dan Berkesenian. Yogyakarta: Cipta Media.

Nukman, Ilhamuddin. 2009. Life to Alive.Yogyakarta: Diva Press

Sahid, Nur. Semiotika untuk Teater dan Tari. 2016. Semarang: Gigih Pustaka Mandiri.

Smith, Jacqueline. 1985. Dance Composition A Practical Guide for Teacher Komposisi Tari: Sebuah Petunjuk Praktis Bagi Guru. Terjemahan Ben Suharto. Yogyakarta: Ikalasi.

Wanganea, Yopie. 1985. Upacara Tradisional Yang Berkaitan Dengan Peristiwa Alam dan Kepercayaan Daerah Khusus Ibukota Jakarta. Jakarta: Depdikbud DKI Jakarta.

\section{B. Discografi}

1. “Kotebang” karya Abdul Rachem 1992

2. "Lenggang Nyai" karya Wiwiek Widyastuti 1998

3. "Ronggeng Cukin” karya Satri Ari Utami 2010

4. "Duh Nyai” karya Novianti 2015

\section{Webtografi}

1. https://mynameis8.wordpress.com, diunggah pada 1 agustus 2013 diunduh tgl 1 septemper 2016.

2. http//wikipedia.com, diunggah pada 19 mei 2013 diunduh tgl 1 september 2016

3. Condet-betawi.blogspot.com, diunggah pada 10 agustus 2013 diunduh tgl Desember 2016.
4. Situs-betawi.blogspot.com, diunggah pada 16 Januari 2016 diunduh tgl 7 Desember 2016 
